\title{
RADIOGRAPHIC EVOLUTION AND CERVICAL SAGITAL BALANCE OF LAMINOPLASTY VERSUS LAMINECTOMY IN PATIENTS WITH CERVICAL SPONDYLOTIC MYELOPATHY
}

\author{
EVOLUÇÃO RADIOGRÁFICA E EQUILÍBRIO SAGITAL CERVICAL DA LAMINOPLASTIAX \\ LAMINECTOMIA EM PACIENTES COM MIELOPATIA CERVICAL ESPONDILÓTICA
}

EVOLUCIÓN RADIOGRÁFICA Y EQUILIBRIO SAGITAL CERVICAL DE LA LAMINOPLASTIA
VERSUS LAMINECTOMÍA EN PACIENTES CON MIELOPATÍA CERVICAL ESPONDILÓTICA

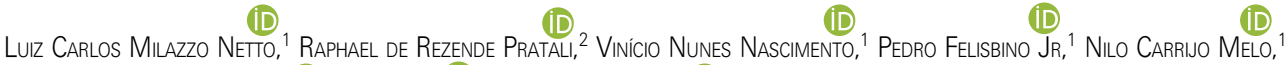 \\ Brenda Cristina Ribeiro Araúso, ${ }^{3}$ Sérgio Daher, ${ }^{3}$ Murilo Tavares DaHer ${ }^{1,4}$ \\ 1. Centro de Reabilitação e Readaptação Dr. Henrique Santillo - CRER, Spine Group, Goiânia, GO, Brazil. \\ 2. Hospital do Servidor Público Estadual de São Paulo - HSPE-SP, Spine Group, São Paulo, SP, Brazil. \\ 3. Centro de Reabilitação e Readaptação Dr. Henrique Santillo - CRER, Goiânia, GO, Brazil. \\ 4. Universidade Federal de Goiás, Faculdade de Medicina, Department of Orthopedics and Traumatology - DOT/FM/UFG, Goiânia, GO, Brazil.
}

\begin{abstract}
Objective: To compare radiographic findings of patients who underwent laminoplasty and laminectomy with arthrodesis for spondylotic cervical myelopathy. Methods: Who were submitted to laminectomy with arthrodesis or laminoplasty to treat cervical spondylotic myelopathy with minimum follow-up of 6 months. The radiographic parameters related to the cervical spine evaluated were C0C2 lordosis (C0C2), cervical lordosis (CL), T1 slope (T1S), thoracic inlet angle (TIA), neck tilt (NT), cervical sagittal vertical axis (CSVA), and T1S - CL mismatch (T1S-CL). Results: We evaluated 34 patients, 23 (68\%) of whom were men. The mean age was 65 years (SD \pm 13 ). There was no statistical difference in any of the preoperative radiographic parameters. Considering the patients submitted to laminectomy alone, a significant difference was observed for COC2 ( $P=0.045)$, CSVA $(P=0.0008)$, with differences between IPO and POS times $(P=0.026)$ and between $P R E$ and $P O S(P$ $=0.0013)$ and T1S $-C L$ mismatch $(P=0.0004)$, with a difference between IPO and POS $(P=0.0076)$ and between $P R E$ and $P O S(P=0.001)$. Considering the patients submitted to laminoplasty alone, there was no difference over time for any radiographic parameters considered. Comparing the radiographic parameters between the laminectomy and laminoplasty groups in the three time periods, there was no significant difference for any of them. Conclusion: This study suggests that patients with cervical spondylotic myelopathy who underwent laminectomy with instrumentation may present worse radiographic evolution as regards cervical sagittal alignment over time when compared to patients who underwent laminoplasty. Level of evidence III; Retrospective case series.
\end{abstract}

Keywords: Spine; Spinal Cord Compression; Treatment Outcome; Spondylosis.

\section{RESUMO}

Objetivo: Comparar os resultados radiográficos de pacientes submetidos à cirurgia de laminoplastia e laminectomia e artrodese para o tratamento de mielopatia cenvical espondilótica. Métodos: Pacientes submetidos à laminectomia e artrodese ou laminoplastia para o tratamento de mielopatia cervical espondilótica com acompanhamento mínimo de seis meses. Os parâmetros radiográficos relacionados à coluna cervical avaliados foram: Lordose COC2 (COC2); Lordose cervical (LC); Inclinação de T1 (IT1); Ângulo de entrada do tórax (AET); Versão do pescoço (VP); Eixo sagital vertical cenvical (ESVC); Diferença entre IT1 e LC (IT1-LC). Resultados: Avaliaram-se 34 pacientes, sendo 23 (68\%) homens. A idade média foi de 65 anos (DP: \pm 13$)$. Não houve diferença estatística em nenhum dos parâmetros radiográficos pré-operatórios. Considerando isoladamente os pacientes submetidos à laminectomia, notou-se diferença significativa C0-C2 $(P=0,045)$, ESVC $(P=0,0008)$, sendo observada diferença entre os tempos $P O I$ e POS $(P=0,026)$ e entre PRE e POS $(P=0,0013)$ e diferença IT1 $-L C(P=0,0004)$ com diferença entre $P O I$ e $P O S(P=0,0076)$ e entre PRE e POS $(0,001)$. Considerando isoladamente os pacientes submetidos à laminoplastia, não houve diferença ao longo do tempo para nenhum dos parâmetros considerados. Comparando-se os parâmetros radiográficos entre os grupos laminectomia e laminoplastia nos três tempos, não houve diferença significativa para nenhum deles. Conclusões: O estudo sugere que os pacientes portadores de mielopatia cervical submetidos a laminectomia com instrumentação possam apresentar pior evolução radiográfica quanto ao alinhamento sagital cervical ao longo do tempo quando comparados aos pacientes submetidos a laminoplastia. Nível de evidência III; Série de casos retrospectiva.

Descritores: Coluna Vertebral; Compressão da Medula Espinhal; Resultado do Tratamento; Espondilose.

\section{RESUMEN}

Objetivo: Comparar los resultados radiográficos de pacientes sometidos a cirugía de laminoplastia y laminectomía y artrodesis para el tratamiento de mielopatía cervical espondilótica. Métodos: Pacientes sometidos a laminectomía y artrodesis o laminoplastia para el tratamiento de mielopatía cervical espondilótica con acompañamiento mínimo de 6 meses. Los parámetros radiográficos relacionados a

Study conducted at the Spine Group of the Centro de Reabilitação e Readaptação Dr. Henrique Santillo - CRER. Rua 70, 351, apto 302, Jardim Goiás, Goiânia, G0, Brasil. 74810-350.

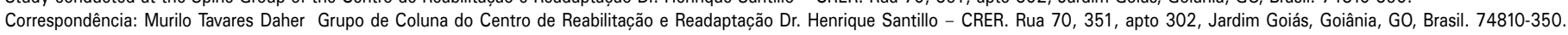
murilodaher@uol.com.br 
la columna cervical evaluados fueron: Lordosis COC2 (COC2); Lordosis cenvical (LC); Inclinación de T1 (IT1): Ángulo de entrada del tórax (AET), versión del cuello (VC); Eje sagital vertical cervical (ESVC); Diferencia entre IT1 y LC (IT1-LC). Resultados: Se evaluaron 34 pacientes, siendo 23 hombres (68\%). La edad promedio fue de 65 años (DP: \pm 13$)$. No hubo diferencia estadística en ninguno de los parámetros radiográficos preoperatorios. Considerando aisladamente a los pacientes sometidos a la laminectomía, se notó diferencia significativa C0-C2 $(P=0,045)$, ESVC $(P=0,0008)$, siendo observada diferencia entre los tiempos $P O I$ y $P O S(P=0,026)$ y entre $P R E$ y $P O S(P=0,0013)$ y diferencia IT1 - LC $(P=0,0004)$ con diferencia entre $P O I$ y POS $(P=0,0076)$ y entre $P R E$ y $P O S(0,001)$. Considerando aisladamente a los pacientes sometidos a laminoplastia, no hubo diferencia a lo largo del tiempo para ninguno de los parámetros radiográficos considerados. Comparándose con los parámetros radiográficos entre los grupos laminectomía y laminoplastia en los tres tiempos, no hubo diferencia significativa para ninguno de ellos. Conclusiones: El estudio sugiere que los pacientes portadores de mielopatía cervical sometidos a laminectomía con instrumentación puedan presentar peor evolución radiográfica cuanto a la alineación sagital cervical a lo largo del tiempo cuando comparados a los pacientes sometidos a laminoplastia. Nivel de evidencia III; Serie de casos retrospectivos.

Descriptores: Columna Vertebral; Compresión de la Médula Espinal; Resultado del Tratamiento; Espondilosis.

\section{INTRODUCTION}

Cervical spondylotic myelopathy (CSM) is the most common cause of non-traumatic spinal cord injury and can lead to high morbidity in the affected patient. ${ }^{1}$

It is usually treated surgically, by either anterior or posterior approach, though the posterior approach is usually reserved for cases of multi-segment compression, more elderly patients, and more serious myelopathy without fixed kyphosis. ${ }^{1}$

The two main posterior access techniques are laminoplasty and laminectomy associated with arthrodesis. Both have similar outcomes from a neurological recovery perspective and there is no consensus around the superiority of one technique over the other. ${ }^{2}$

The influence of the sagittal balance of the thoracolumbar spine on the quality of life and the functional results of patients is increasingly recognized. 3,4 Due to the great complexity of the cervical spine, with broad compensatory mechanisms, the sagittal balance of this region is not yet widely understood. ${ }^{5}$ However, there is evidence that changes in alignment can lead to a poorer quality of life ${ }^{6}$ and a worsening of the myelopathy. ${ }^{5}$

Some authors have demonstrated that postoperative sagittal cervical alignment following laminectomy and arthrodesis ${ }^{7}$ can influence functional outcomes and even predict a worsening of radiographic alignment during postoperative follow-up. ${ }^{8}$

The objective of this study is to compare sagittal cervical alignment and the radiographic progression of patients who underwent laminoplasty and laminectomy associated with arthrodesis for the treatment of cervical spondylotic myelopathy.

\section{METHODS}

Patients

This is a retrospective study based on prospectively collected data. Following approval by the local Institutional Review Board (REC 2.546.077), the medical records and imaging examinations of patients who underwent surgical treatment for cervical spondylotic myelopathy and at least six months of follow-up at a single center.

All cases of myelopathy from other causes (traumatic, tumoral, and infectious), as well as anterior approach cases (discectomy and/or corpectomy), were excluded.

The patients were submitted to laminoplasty or laminectomy and arthrodesis surgery according to the preference of the assisting surgeon.

All laminoplasties were performed according to the technique described by Hirabaishi ${ }^{9}$ and Riew $^{10}$ (open door laminoplasty) and fixed with titanium miniplates $(1.6 \mathrm{~mm}$ plate) with the opening on the most symptomatic side of the lamina. The cases submitted to laminectomy and arthrodesis were performed following the usual technique ${ }^{11}$ with lateral mass instrumentation at the levels between $\mathrm{C} 2$ and $\mathrm{C} 6$ and pedicle screws when fixation was necessary in T1 or T2. Fixation of C7 was accomplished with pedicle or lateral mass screws according to the surgeon's preference (fixation system with $3.3 \mathrm{~mm}$ rods and 3.5 or $4.0 \mathrm{~mm}$ screws). The arthrodesis was always performed at all decompressed levels to prevent iatrogenic instability.

\section{Radiographic analysis}

The imaging evaluation was conducted with radiographs of the cervical spine, radiographs of the total spine, and magnetic resonance. All radiographs were taken at the same center following the same protocol with the patient in orthostasis. The only exceptions were patients with severe myelopathy who could not stand and whose radiographs were taken with them sitting.

The radiographic parameters evaluated were:5,6,12,13 (Figures 1 and 2)

- COC2 lordosis (COC2): the angle formed by the McGregor line and the inferior plateau of $\mathrm{C} 2$

- Cervical lordosis (CL): the angle between the inferior plateaus of $\mathrm{C} 2$ and $\mathrm{C} 7$ as measured by the Cobb method

- T1 slope (T1S): the angle formed by the line of the superior plateau of T1 and the horizontal line (analogous to sacral inclination - SI)

- Thoracic inlet angle (TIA): the angle formed between a line that runs from the apex of the manubrium of sternum to the center of the superior plateau of $\mathrm{T} 1$ and a line perpendicular to the superior plateau of T1 (analogous to the angle of pelvic incidence - PI)

- Neck Tilt (NT): the angle formed between a line that runs from the apex of the manubrium of sternum to the center of the superior plateau of $\mathrm{T} 1$ and the vertical line (analogous to pelvic tilt - PT)

- McGregor slope (McGS): the angle formed by the McGregor line and the horizontal line

- Cervical sagittal vertical axis (CSVA): the horizontal distance between the center of $\mathrm{C} 2$ and the posterior portion of the superior plateau of $\mathrm{C} 7$

- T1S-CL mismatch (T1S - CL): Difference between T1S and CL. The measurements were performed by the same examiner using Surgimap Spine software (Nemaris Inc., New York, NY) at three different times: preoperative (PRE), immediate postoperative (IPO), and at the last radiographic evaluation (POS)

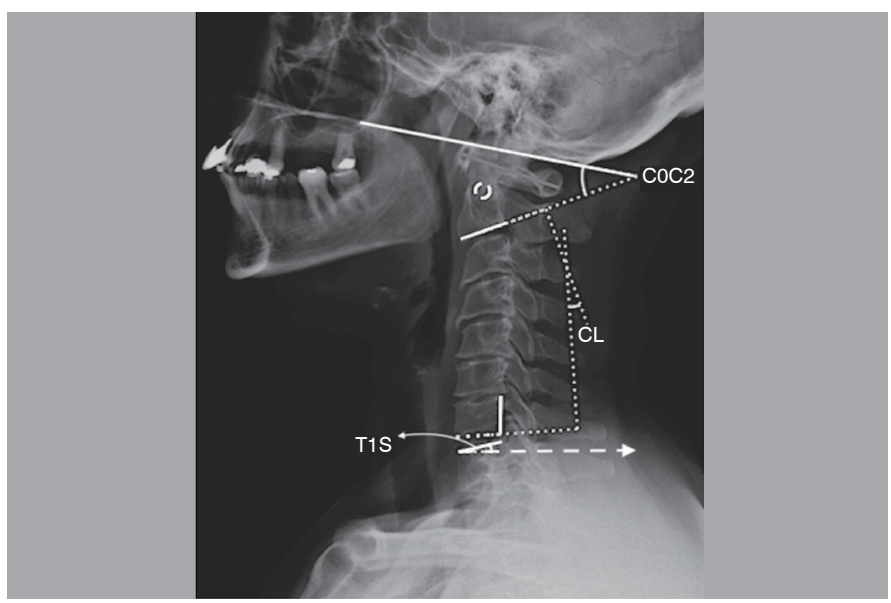

Figure 1. Radiographic parameters evaluated. C0C2 (COC2 lordosis), CL (cervical lordosis), T1S (T1 slope). 


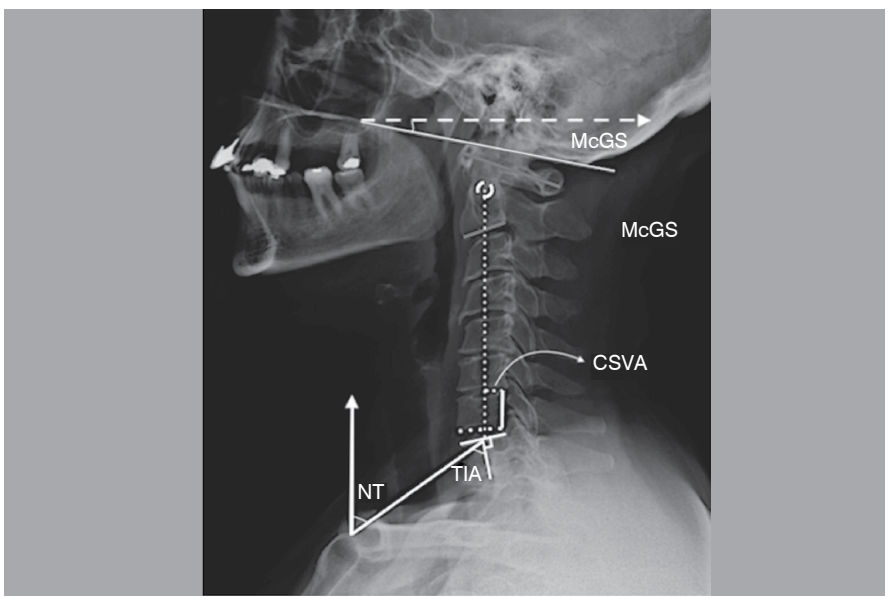

Figure 2. Radiographic parameters evaluated. TIA (thoracic inlet angle), NT (neck tilt), McGS (McGregor slope), CSVA (cervical sagittal vertical axis).

\section{Statistical analysis}

Statistical analysis was performed using $R$ version 3.4 software (R Foundation for Statistical Computing, Vienna, Austria). The data consisted of quantitative variables and distribution normality was verified by the Shapiro-Wilk test. The comparison between the means of the laminectomy and laminoplasty groups was carried out using the Student's t test, following confirmation of the equality of variances of the groups using the F-test. The values of the PRE, IPO, and $\mathrm{POS}$ radiographic parameters were compared using repeated measures ANOVA, since a paired analysis was required. Finally, the evolution of the radiographic parameters of the two groups in the POS and IPO periods was analyzed by comparing the mean difference between the POS and IPO values using the Student's $t$ test. The level of significance considered was $5 \%$.

\section{RESULTS}

\section{Population}

A total sample of 34 patients was evaluated, 23 (68\%) of whom were men and $11(32 \%)$ of whom were women. The mean age was 65 years (SD: \pm 13 ), ranging from 37 to 88 years of age. There was no significant difference between the mean ages of the laminectomy (66 years, SD: \pm 10.7 ) and laminoplasty (64 years, SD: \pm 17.9$)$ groups.

\section{Comparison of the radiographic parameters between the groups}

Table 1 shows the preoperative mean and standard deviation of the preoperative radiographic sagittal alignment parameters of the cervical spine. There was no difference between any of the parameters of the patients in the laminectomy and laminoplasty groups, showing that the groups were radiographically similar.

\section{Evolution of the radiographic parameters during monitoring}

Analyzing the evolution of the radiographic parameters studied during the three monitoring periods (PRE, IPO, and POS), we observed different behaviors in the two groups.

Table 1. Preoperative radiographic parameters compared between the laminectomy and laminoplasty groups. Values of $\mathrm{C} 0-\mathrm{C} 2, \mathrm{CL}$, and T1S in degrees. CSVA values in $\mathrm{mm}$.

\begin{tabular}{c|c|c|c}
\hline $\begin{array}{c}\text { Radiographic } \\
\text { parameter }\end{array}$ & $\begin{array}{c}\text { Laminectomy } \\
\text { Mean (SD) }\end{array}$ & $\begin{array}{c}\text { Laminoplasty } \\
\text { Mean (SD) }\end{array}$ & $\mathbf{P}$ \\
\hline $\mathrm{CO}-\mathrm{C} 2$ & $-20.5(8.3)$ & $-20.7(10.5)$ & 0.9554 \\
\hline $\mathrm{CL}$ & $-16.2(12)$ & $-18.8(17.7)$ & 0.6612 \\
\hline $\mathrm{CSVA}$ & $21.6(13.9)$ & $19.1(14.2)$ & 0.6431 \\
\hline $\mathrm{T} 1 \mathrm{~S}$ & $29.6(11.4)$ & $31.2(10.6)$ & 0.7065 \\
\hline $\mathrm{T} 1 \mathrm{~S}-\mathrm{CL}$ & $13.5(7.5)$ & $12.4(12)$ & 0.7821 \\
\hline \multicolumn{4}{|r}{}
\end{tabular}

Considering the patients submitted to laminectomy by themselves, we observed a significant difference in C0-C2 $(P=0.045)$, with no difference in the comparison between each time period using the complementary Bonferroni test (Figure 3$)$; in CSVA $(P=0.0008)$, where we observed a difference between IPO and POS $(P=0.026)$ and between PRE and POS ( $P=0.0013$ ) values (Figure 4); and in the T1S - CL mismatch ( $P=0.0004)$, with differences between IPO and POS $(P=0.0076)$ and $P R E$ and POS (0.001) (Figure 5). There were no significant differences in $\mathrm{CL}$ or T1S.

Considering the patients submitted to laminoplasty by themselves, there were no differences between the time periods for any of the radiographic parameters analyzed.

Comparing the radiographic parameters between the laminectomy and laminoplasty groups in the three monitoring time periods, there was no significant difference for any of the parameters $(C 0-C 2, P=0.898$; $C L, P=0.557$; CSVA, $P=0.459 ; T 1 S, P=0.631 ; T 1 S-C L, P=0.110$ ).

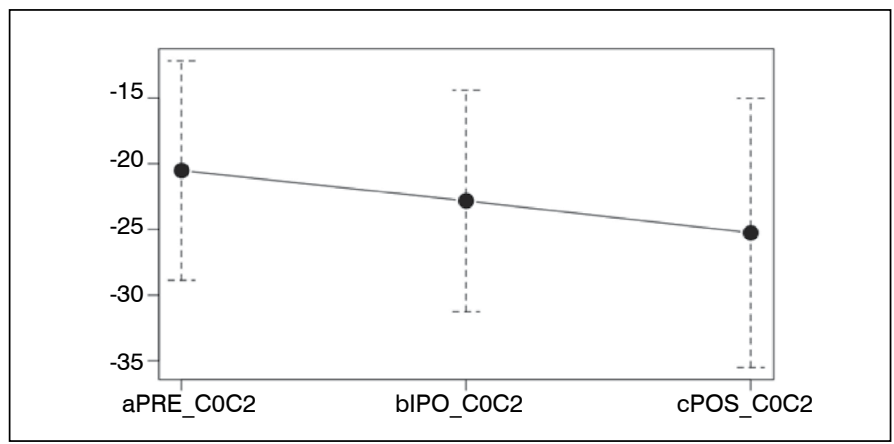

Figure 3. Evolution of COC2 in relation to PRE, IPO, and POS timeframes in patients who underwent laminectomy. There was significant difference between the times $(P=0.045)$.

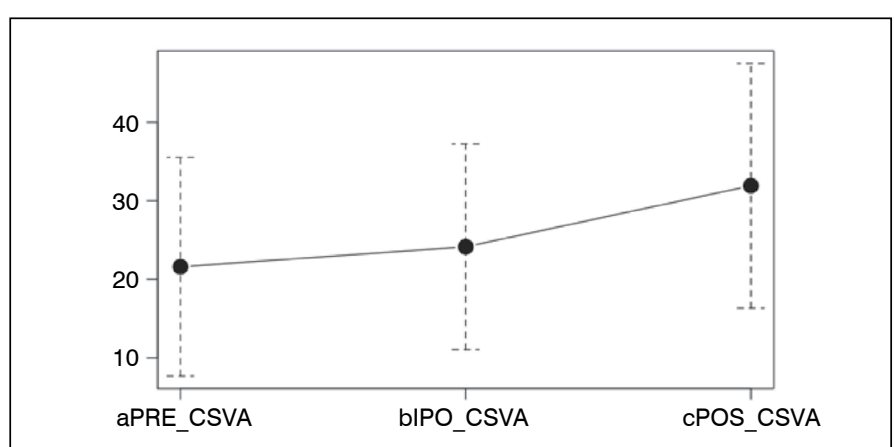

Figure 4. Evolution of CSVA in relation to PRE, IPO, and POS timeframes in patients who underwent laminectomy. There was significant difference between the times $(P=0.0008)$, with differences being observed between IPO and POS $(P=0.026)$ and between PRE and POS $(P=0.0013)$.

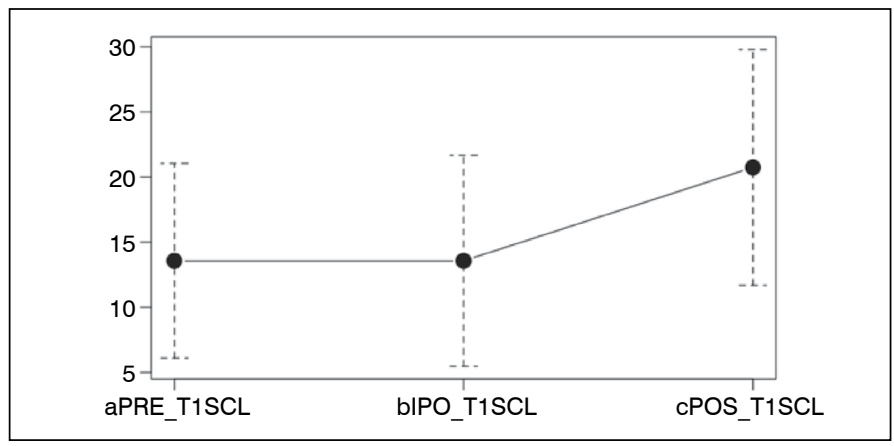

Figure 5. Evolution of T1S - CL mismatch in relation to PRE, IPO, and POS timeframes in patients who underwent laminectomy. There was significant difference between the times $(P=0.0004)$, with differences being observed between IPO and POS $(P=0.0076)$ and between PRE and POS $(P=0.001)$. 


\section{Behavior of the radiographic parameters following the surgical procedure}

The comparison of the radiographic parameters studied between the laminectomiy and laminoplasty groups following the surgical procedure were conducted comparing the means of the difference between the POS and IPO values of each parameter. As can be seen in Table 2, there was no significant difference between the groups for any of the radiographic parameters.

Table 2. Comparison of laminectomy and laminoplasty group values obtained for the difference between the POS and IPO time periods. Values of $\mathrm{C} 0-\mathrm{C} 2, \mathrm{CL}$, and T1S in degrees. CSVA values in $\mathrm{mm}$.

\begin{tabular}{c|c|c|c}
\hline $\begin{array}{c}\text { Radiographic } \\
\text { parameter }\end{array}$ & $\begin{array}{c}\text { Laminectomy } \\
\text { Mean (SD) }\end{array}$ & $\begin{array}{c}\text { Laminoplasty } \\
\text { Mean (SD) }\end{array}$ & $\mathbf{P}$ \\
\hline $\mathrm{CO}-\mathrm{C} 2$ & $-2.4(7.4)$ & $-2.5(7.9)$ & 0.9695 \\
\hline $\mathrm{CL}$ & $3.2(10.1)$ & $-0.5(8.2)$ & 0.2579 \\
\hline $\mathrm{CSVA}$ & $7.7(12.9)$ & $2.2(15.6)$ & 0.3231 \\
\hline $\mathrm{T} 1 \mathrm{~S}$ & $3.1(8.5)$ & $0.5(6.5)$ & 0.331 \\
\hline $\mathrm{T} 1 \mathrm{~S}-\mathrm{CL}$ & $7.1(10.1)$ & $0.3(8.9)$ & 0.05796 \\
\hline \multicolumn{4}{|r}{}
\end{tabular}

\section{DISCUSSION}

The ideal surgical approach for the treatment of CSM is a subject of discussion in the literature. Generally, the posterior approach is reserved for more serious cases of myelopathy, more diffuse disease, and cases without fixed kyphotic deformity. The decision about the access route is usually only based on regional cervical spine radiographs and magnetic resonance data. ${ }^{1}$

There are several studies showing the importance of cervical alignment to clinical and quality of life outcomes in certain patient populations. ${ }^{14-17}$ However, the cervical spine is a complex region with a great range of motion. This mobility allows greater adaptation to the changes typical to aging. These adaptations occur in the cervical region, especially to maintain the line of vision on the horizon.

This study did not find any difference in preoperative sagittal alignment between the two groups evaluated. However, Lau et al. ${ }^{12}$ showed that laminoplasty was more common in patients with high $\mathrm{CL}$. This difference may be related to the fact that the choice of technique in our population was based on the preference of the surgeon rather than on any well-established criteria.

The LAMINOPLASTY group did not present any radiographic worsening over time. However, patients who underwent LAMINECTOMY presented worsening of C0-C2 lordosis, CSVA, and T1S-LL parameters. These results were not expected following arthrodesis, which theoretically should prevent worsening of alignment in the fixed segment. One hypothesis is that with the arthrodesis the segments lose the capacity to compensate, which can predispose the adjacent segments to degeneration and thus worsen the radiographic parameters. The patients with laminoplasty maintained alignment during the entire follow-up. These results conflict with some studies in the literature. For example, Lau et al. demonstrated that alignment worsened more following laminoplasty as compared to laminectomy. ${ }^{12}$ Radiographic worsening related to laminoplasty was associated with T1S greater than $30^{\circ}$, which is a strong indicator of thoracolumbar sagittal inbalance. ${ }^{15}$

This worsening following laminoplasty observed in other studies but not in our case series can be justified by the small number of patients in this group and for technical reasons in performing the surgeries (to avoid resecting the facet joint and a concern with preserving the cervical musculature that inserts into C2).

The increase in $\mathrm{COC} 2$ lordosis observed in the laminectomy patients can probably be related to a compensatory mechanism of the cervical spine to ensure horizontal vision, as observed by other studies. ${ }^{13}$

There was no difference between the groups at the three evaluation times.

This study has the following limitations:

First, its retrospective nature, even though the data was collected prospectively.

In addition, the clinical parameters, which might be correlated to the radiographic differences in functional results observed between the groups, were not evaluated. This could be included in a future study.

A larger sample is necessary to make any inferences, which is difficult due to the rarity of the disease.

\section{CONCLUSION}

This study suggests that patients with cervical spondylotic myelopathy submitted to laminectomy with instrumentation may present worse radiographic evolution in terms of sagittal cervical alignment over time than patients submitted to laminoplasty.

All authors declare no potential conflict of interest related to this article.

CONTRIBUTION OF THE AUTHORS: Each author made significant individual contributions to this manuscript. MTD conceptualized the study, assisted with the manuscript, and was the surgeon in most of the cases. LCM wrote the manuscript and collected the data. VNN, NCM and PFJ assisted in data collection and patient care. BCRA is the monitor of the study center and assisted with the bibliographical review. SD is the senior physician of the group and assisted with the idea. RRP assisted with the statistics.

\section{REFERENCES}

1. Meluzzi A, Taricco MA, Brock RS, Dias MRP, Nakaguawa G, Guirado VMP, et al . Fatores prognósticos associados ao tratamento cirúrgico da mielorradiculopatia espondilótica cervical. Coluna/Columna. 2012;11(1):52-62

2. Fehlings MG, Barry S, Kopjar B, Yoon ST, Arnold P, Massicotte EM, et al. Anterior versus posterior surgical approaches to treat cervical spondylotic myelopathy: outcomes of the prospective multicenter AOSpine North America CSM study in 264 patients. Spine (Phila Pa 1976). 2013:38(26):2247-52

3. Yoon ST, Hashimoto RE, Raich A, Shaffrey $\mathrm{Cl}$, Rhee JM, Riew KD. Outcomes after laminoplasty compared with laminectomy and fusion in patients with cervical myelopathy: a systematic review. Spine (Phila Pa 1976). 2013;38(22 Suppl 1):S183-94

4. Ames CP, Blondel B, Scheer JK, Schwab FJ, Le Huec JC, Massicotte EM, et al. Cervical radiographical alignment: comprehensive assessment techniques and potential importance in cervical myelopathy. Spine (Phila Pa 1976). 2013:38(22 Suppl 1):S149-60.

5. Bao H, Varghese J, Lafage R, Liabaud B, Diebo B, Ramchandran S, et al. Principal Radiographic Characteristics for Cervical Spinal Deformity: A Health-related Qualityof-life Analysis. Spine (Phila Pa 1976). 2017;42(18):1375-82.

6. Kim TH, Lee SY, Kim YC, Park MS, Kim SW. T1 slope as a predictor of kyphotic align ment change after laminoplasty in patients with cervical myelopathy. Spine (Phila Pa 1976). 2013;38(16):E992-7.

7. Hirabayashi K, Watanabe K, Wakano K, Suzuki N, Satomi K, Ishii Y. Expansive open-door laminoplasty for cervical spinal stenotic myelopathy. Spine (Phila Pa 1976). 1983;8(7):693-9.

8. Riew KD, Raich AL, Dettori JR, Heller JG. Neck Pain Following Cervical Laminoplasty: Does Preservation of the C2 Muscle Attachments and/or C7 Matter? Evid Based Spine Care J. 2013:4(1):42-53
9. Manzano GR, Casella G, Wang MY, Vanni S, Levi AD. A prospective, randomized trial comparing expansile cervical laminoplasty and cervical laminectomy and fusion for multilevel cervical myelopathy. Neurosurgery. 2012;70(2):264-77.

10. Scheer JK, Tang JA, Smith JS, Acosta FL, Protopsaltis TS, Blondel B, et al. Cervical spine alignment, sagittal deformity, and clinical implications: a review. J Neurosurg Spine. 2013;19(2):141-59.

11. Tan LA, Riew KD, Traynelis VC. Cervical Spine Deformity-Part 1: Biomechanics, Radiographic Parameters, and Classification. Neurosurgery. 2017;81(2):197-203.

12. Lau D, Winkler EA, Than KD, Chou D, Mummaneni PV. Laminoplasty versus laminectomy with posterior spinal fusion for multilevel cervical spondylotic myelopathy: influence of cervical alignment on outcomes. J Neurosurg Spine. 2017;27(5):508-17.

13. Bridwell KH, Dewald RL. The textbook of spinal surgery. J Pediatr Orthop. 1997;17(4):540.

14. Le Huec J, Demezon H, Aunoble S. Sagittal parameters of global cervical balance using EOS imaging: normative values from a prospective cohort of asymptomatic volunteers. Eur Spine J. 2015;24(1):63-71.

15. Sakai K, Yoshii T, Hirai T, Arai Y, Torigoe I, Tomori M, et al. Cervical sagittal imbalance is a predictor of kyphotic deformity after laminoplasty in cervical spondylotic myelopathy patients without preoperative kyphotic alignment. Spine (Phila Pa 1976). 2016;41(4):299-305

16. Kim TH, Lee SY, Kim YC, Park MS, Kim SW. T1 slope as a predictor of kyphotic alignment change after laminoplasty in patients with cervical myelopathy. Spine (Phila Pa 1976). 2013:38(16):E992-7.

17. Tang JA, Scheer JK, Smith JS, Deviren V, Bess S, Hart RA, et al. The impact of standing regional cervical sagittal alignment on outcomes in posterior cervical fusion surgery. Neurosurgery. 2012;71(3):662-9 